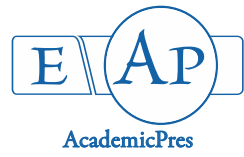

\title{
Determination of Heavy Metal Levels in Echium italicum L. Plants
}

\section{Esra UÇAR ${ }^{1 *}$, Mehmet Arif OZYAZICI² ${ }^{2}$ Sevda ÖZEL ${ }^{3}$, Tolga KARAKÖY ${ }^{1}$, Filiz ÖKTÜREN ASRI ${ }^{4}$, Gülşah Kütük DINÇEL ${ }^{1}$, Burak DINÇEL ${ }^{5}$}

\author{
${ }^{1}$ Cumburiyet University, Sivas Vocational School, Department of Crop and Animal Production, 58140, Sivas, \\ Turkey; eucar@cumburiyet.edu.tr ("correspondingauthor);tolgakarakoy73@hotmail.com \\ ${ }^{2}$ Siirt University, Faculty of Agriculture, Department of Field Crops, Turkey \\ ${ }^{3}$ Cumburiyet University, Department of Geophysical Enigneering, Sivas 58140,Turkey; svd.zel@gmail.com \\ ${ }^{4}$ Bati Akdeniz Agricultural Research Institute, Antalya,Turkey; filizokturen@hotmail.com \\ ${ }^{5}$ Cumburiyet University, Agricultural Economics, Agricultural Plant Science, Agricultural Philosophy, Sivas, \\ Turkey; tolgakarakoy73@hotmail.com
}

\begin{abstract}
Plants and their components have maintained importance in human life as medicinal and aromatic ingredients that have been used by people for many centuries. Nature is the chief source of these valuable resources and humans use these plants directly after collection from their habitat. Therefore, the places where such plants grow have become highly important for understanding the role and behaviour of the accumulation of various elements, especially heavy metals. The aim of the present study was to evaluate the levels of heavy metals in Echium italicum L. plants collected from seven different locations in the province of Sivas in Northern Turkey. Heavy metal pollution was determined in the analysis of the plants. A significant difference was observed in the amounts of heavy metals between plants growing in areas with high vehicle traffic and in the plants growing in low traffic areas. This is of great importance for medical and aromatic plants, which are usually collected from areas of natural growth. Therefore, when these plants are collected from the wild, low traffic areas should be selected.
\end{abstract}

Keywords: Echium italicumL; heavy metal; $\mathrm{Pb}-\mathrm{Cd}-\mathrm{Hg}$; pollution

\section{Introduction}

Echium italicum L. is a perennial plant commonly known as Italian bugloss, which belongs to the Boraginaceae family. As a medicinal plant, E. italicum L. has attracted great interest as the red pigmented roots have been widely used to treat burns and wounds. Similarly, the essential oil is very popular because of high antimicrobial activity (Morteza-Semnani et al., 2009). E. italicum L. is found throughout several continents, whereas Australia, Europe, Mediterranean and Asian countries contain a huge diversity of this plant (Rechinger, 1967).

Turkey is considered a diversity hot spot and centre of origin for various crops, mainly due to differences in climatic, geographic and geomorphologic conditions (Karakoy et al., 2012, 2014; Baloch et al., 2014). A total of 9 Echium species have been reported in Turkey (E. italicum L., E. angustifolium Miller, E. plantagineum L., E. orientale L., E. russicum J.F.Gmel., E. arenarium Guss, E. glomeratum Poir., E. vulgare L., E. parviflorum Moench). Of these 9 species, E. italicum L. and E. vulgare L. are the most widely distributed in Turkey and most commonly used for ethnopharmacological purposes.
Echium mainly grows in Central and South Europe and South-West Asia, while is scattered throughout Turkey (Edmondson, 1978). This plant grows rapidly as a weed in forests and on agricultural land (Yildırım and Ekin, 2003). At the same time, Echium species are cultivated in Europe and England (Berti et al., 2007) and the flowers are used as medicine in France. It is used for infectious diseases in traditional medicine of Iran (Mohsen Abolhassani, 2004). It has also been reported to be a urine enhancer, an emollient, an antidepressant and to have positive effects on wound healing and the relief of rheumatism pain (Tabata et al., 1994; Pardo et al., 2000; Fujita et al., 2013).

The main chemical constituents of the plant are shikonin derivatives, flavonoids, phenolic acids, pyrrolizidine alkaloids and fatty acids (Eruygur, 2012). Fatty acids such as omega-3 and omega-6, which are present in the plant in large quantities, are beneficial for certain types of cancer, heart and skin disorders (Coupland, 2008).

Micronutrients such as Iron $(\mathrm{Fe})$, zinc $(\mathrm{Zn})$, manganese $(\mathrm{Mn})$, copper $(\mathrm{Cu})$, nickel $(\mathrm{Ni})$, molybdenum $(\mathrm{Mo})$ and cobalt $(\mathrm{Co})$ are essential for plant life, whereas heavy metals such as chromium $(\mathrm{Cr})$, cadmium $(\mathrm{Cd})$, mercury $(\mathrm{Hg})$ and lead $(\mathrm{Pb})$ are of no benefit for plants (White, 2012). These heavy metals, even in small concentrations, may result in 
toxic effects on living organisms; pollute the environment by producing exhaust gases, industrial waste, agricultural pesticides and chemical fertilizers. Environmental waste has become an important concern. With the passage of time, these heavy metals accumulate in the soil and have drastic effects on soil fertility, microbial activity, and biodiversity and even on human beings by creating toxic effects on human and animals through the food chain (Robinson, 1997; Tong et al., 2017; Wu et al., 2018; RodríguezBocanegra et al., 2018).

The main objective of the present study was to investigate the levels of various heavy metals in Echium italicum L. plants collected from different regions of Turkey. It was also aimed to investigate the effect of the area of plant growth on the heavy metal levels in the plants.

\section{Materials and Methods}

The obtaining of plant materials

The study was conducted in Cumhuriyet University Sivas Vocational School and West Mediterranean Agricultural Research Laboratories (Antalya) in 2016.

Plant and soil samples were collected from seven different locations around Sivas (Turkey) (Table 1, Fig. 1). Samples were collected of both the below-ground and above-ground sections of the plant parts.

Concentrations of various heavy metals, primarily cadmium and lead, were then determined.

Soil samples were also taken at a depth of $30 \mathrm{~cm}$ from the soil where the plants were growing and the heavy metal levels in these samples were determined.

Table 1. The locations of the plant and soil samples

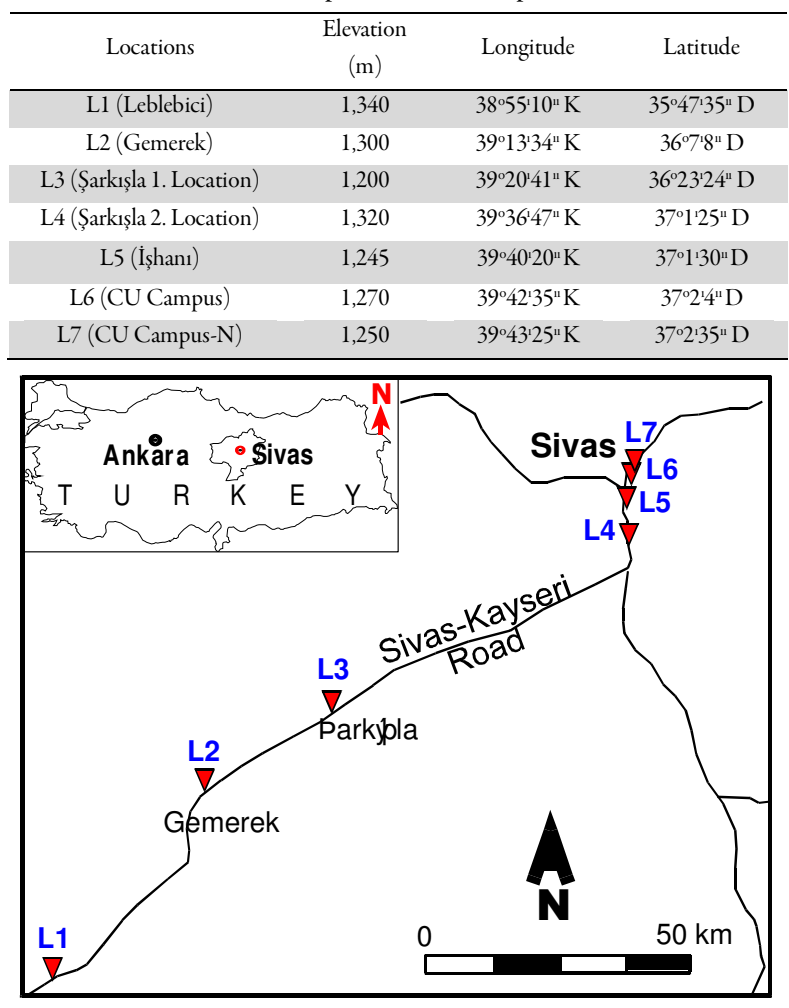

Fig. 1. Locations map
Determination of heavy metal levels in biological samples

For mineral analysis, samples were taken from the mature or fully expanded leaves of the plants. Leaf samples were washed with distilled water three times and then dried in a forced-air oven at $65^{\circ} \mathrm{C}$ to a constant weight. Each leaf sample was separately ground in a stainless steel mill and was then passed through a 20-mesh screen and the analytical process was performed as stated by Kaçar and İnal (2008). Using wet-digested samples via ICP (17), concentrations of various elements, including $\mathrm{Cd}, \mathrm{Co}, \mathrm{Ni}, \mathrm{Zn}, \mathrm{Mn}, \mathrm{Pb}$ and $\mathrm{Cr}$ in the same solution were determined (Kaçar and İnal 2008).

\section{Results and Discussion}

The results of the analysis of various heavy metals in the soil samples collected from 7 different regions of Sivas are shown in Table 2. The maximum and minimum concentrations of these elements, with some relevant properties are given in Table 3 . The range of total heavy metal and micronutrients of $\mathrm{Cd}, \mathrm{Co}, \mathrm{Cr}, \mathrm{Ni}, \mathrm{Pb}, \mathrm{Cu}$ and $\mathrm{Zn}$ in the soil samples were determined as $0.30-2.50,14.50$ $26.50,122.30-181.30,149.70-306.90,12.70-35.40,20.40-$ 57.60 and 54.60-88.20 ppm respectively (Table 3).

The total concentration of $\mathrm{Cd}, \mathrm{Pb}, \mathrm{Cu}$ and $\mathrm{Zn}$ in the soil taken from the E. italicum L. growing areas was lower compared to the values reported in the official report of soil pollution (Anonymous, 2005) (Table 2, Table 4). Kloke (1980) recommended a maximum cadmium limit in the soil of 3 ppm, while Alloway (1968) reported an average of $0.06 \mathrm{ppm}$ cadmium with a range of $0.01-7 \mathrm{ppm}$. Therefore, it can be assumed that $E$. italicum L. plays an important role in lowering $\mathrm{Cd}$ concentrations and there are no $\mathrm{Cd}$ pollution problems where $E$. italicum L. plants are grown. According to Alloway (1990), 54-58\% of soil Cd contamination is due to the application of phosphorus fertilizers, $39-47 \%$ is from the atmosphere and $2-5 \%$ is due to sewage waste. Moen et al. (1986) reported that $\mathrm{Cd}$ is present in the range of 0.01 to $1 \mathrm{ppm}$ in uncontaminated soil. The limit values of Cd vary according to the countries, with levels of 0.5 in Denmark, Finland and Sweden, 2 in France, 1.5 in Germany, 1 in Spain, 3 in the UK and 20 ppm in the USA. Haktanir et al. (1995) reported that the concentration of $\mathrm{Pb}$ is higher near traffic areas and lower in the soil away from traffic areas, with reported levels of 120 $\mathrm{ppm} \mathrm{Pb}$ in soil near to traffic and $25 \mathrm{ppm} \mathrm{Pb}$ in soil away from traffic and in uncontaminated areas. Horvath (1995) reported that soil $\mathrm{Pb}$ content can reach up to $1000 \mathrm{ppm}$ in areas under intense pollution from industrial, urban and traffic-related activity. Bergmann (1993) and Alloway (1990) stated that the $\mathrm{Pb}$ content of uncontaminated soil was in the range of 1-20 ppm and 2-300 ppm respectively in normal conditions. El-Bassam and Tğetjen (1977) and Kloke (1980) emphasized that these values are $100 \mathrm{ppm}$. Taking the findings of earlier reports into consideration, it can be said that the soil where E. italicum L. is grown is not exposed to $\mathrm{Pb}$ pollution. The main reasons for $\mathrm{Cu}$ contamination are industrial activities or agricultural spraying; Schwertmann and Huit (1975) and Alloway (1990) reported that the total $\mathrm{Cu}$ content of the soil can range from 2 to $250 \mathrm{ppm}$. Other reports (El-Bassam and Tğetjen, 1977; Kloke, 1980; KabataPendias and Pendias, 1992) have emphasised that a $\mathrm{Zn}$ level 
426

of $300 \mathrm{ppm}$ is toxic for plants. In comparison with these ranges for both elements, no pollution or toxicity of these elements was determined in the studied soils due to the presence of $E$. italicum L.

Table 2. Results of heavy metal analysis of soil samples (ppm)

\begin{tabular}{|c|c|c|c|c|c|c|c|c|}
\hline No & $\mathrm{Cd}$ & Co & $\mathrm{Cr}$ & $\mathrm{Ni}$ & $\mathrm{Pb}$ & $\mathrm{Cu}$ & $\mathrm{Zn}$ & $\mathrm{Mn}$ \\
\hline $\mathrm{Ll}$ & 0.3 & 22.3 & 134.3 & 264.7 & 12.7 & 20.4 & 54.6 & 844.1 \\
\hline $\mathrm{L} 2$ & 1.3 & 26.5 & 122.3 & 191.0 & 24.9 & 40.4 & 81.1 & 1037.3 \\
\hline L3 & 0.6 & 25.3 & 144.5 & 255.5 & 21.3 & 39.9 & 73.7 & 1050.1 \\
\hline L4 & 0.8 & 25.3 & 163.2 & 254.8 & 20.2 & 39.8 & 74.1 & 1073.8 \\
\hline $\mathrm{L} 5$ & 0.7 & 22.6 & 163.0 & 265.1 & 16.4 & 32,2 & 58.4 & 1045.3 \\
\hline L6 & 2.5 & 14.5 & 142.9 & 149.7 & 35.4 & 30.5 & 83.1 & 665.7 \\
\hline L7 & 0.8 & 26.1 & 181.3 & 306.9 & 25.1 & 57.6 & 88.2 & 967.3 \\
\hline
\end{tabular}

Table 3. The descriptive statistics of heavy metal content of soils $(n=7)$

\begin{tabular}{|c|c|c|c|c|c|c|c|c|}
\hline Parameters & $\mathrm{Cd}$ & $\mathrm{Co}$ & $\mathrm{Cr}$ & $\mathrm{Ni}$ & $\mathrm{Pb}$ & $\mathrm{Cu}$ & $\mathrm{Zn}$ & $\mathrm{Mn}$ \\
\hline Minimum & 0.30 & 14.50 & 122.30 & 149.70 & 12.70 & 20.40 & 54.60 & 665.70 \\
\hline Maximum & 2.50 & 26.50 & 181.30 & 306.90 & 35.40 & 57.60 & 88.20 & 1073.80 \\
\hline Average & 1.00 & 23.23 & 150.21 & 241.10 & 22.29 & 37.26 & 73.31 & 954.80 \\
\hline Stickiness & 3.60 & 3.79 & -0.61 & 0.34 & 1.11 & 1.42 & $-1,06$ & 1.62 \\
\hline Distortion & 1.80 & -1.88 & 0.23 & -0.91 & 0.72 & 0.50 & -0.60 & -1.51 \\
\hline Hydrangea & 0.80 & 25.30 & 144.50 & 255.50 & 21.30 & 39.80 & 74.10 & 1037.30 \\
\hline StdS & 0.73 & 4.18 & 20.07 & 52.79 & 7.29 & 11.49 & 12.59 & 149.57 \\
\hline Variance & 0.53 & 17.50 & 402.84 & 2786.94 & 53.10 & 132.09 & 158.56 & 22371.52 \\
\hline DK & 72.57 & 18.01 & 13.36 & 21.90 & 32.70 & 30.85 & 17.18 & 15.67 \\
\hline
\end{tabular}

Table 4. Heavy metal limit values in the ground (Moen et al., 1986)

\begin{tabular}{cccc}
\hline Heavy Metal (Total) & $\mathrm{pH} 5-6(\mathrm{ppm})$ & 50 & $\mathrm{pH}(\mathrm{ppm})$ \\
\hline $\mathrm{Pb}$ & 1 & 3 \\
$\mathrm{Cd}$ & 100 & 50 \\
$\mathrm{Cr}$ & 50 & 100 \\
$\mathrm{Cu}$ & 30 & 140 \\
$\mathrm{Ni}$ & 150 & 300 \\
$\mathrm{Zn}$ & - & 20 \\
$\mathrm{Co}$ & & 35 \\
\hline
\end{tabular}

The total concentrations of $\mathrm{Co}, \mathrm{Cr}$ and $\mathrm{Ni}$ in all of the surveyed soils (except one sample for Co) were above the limit value officially reported (Anonymous, 2005) (Table 4). A possible reason for the excess of these elements could be the soil parental material. Smith (1990) identified Co concentrations in the range of 40-200 ppm, 10-20 ppm and 1-3 ppm in Scottish soils from serpentine, andesite and granite deposits, respectively. Bourrelier and Bertelin (1998) stated that the $\mathrm{Cr}$ contents of soils that formed on serpentine generally vary between 0 and $200 \mathrm{ppm}$. Dixon (1989) concluded that soil originated from serpentine parental rock contains higher concentrations of $\mathrm{Cr}$ and $\mathrm{Ni}$.

Mengel (1991) reported soil Co concentrations in a range of 0.2-31 ppm, while Alloway (1990) reported the total $\mathrm{Cr}$ limit in soil in the range of $5-1500 \mathrm{ppm}$ and Kabata-Pendias (1992) stated that the average Ni content of the earth's soil is $2.2 \mathrm{ppm}$. Different investigators have accepted $100 \mathrm{ppm}$ as the limit for total $\mathrm{Cr}$ concentration in the soil (El-Bassam ve Tğetjen, 1977; Kloke, 1980). The limit value of total $\mathrm{Ni}$ for toxicity in soil has been reported as 100 ppm by El-Bassam ve Tğetjen (1977) and Linzon (1978) and 35 ppm by Goncharuk and Sidorenka (1986).

\section{Heavy metal ratio of Echium italicum L.plants}

Analysis of various heavy metals in soil samples collected from various soils where $E$. italicum $\mathrm{L}$. was found are presented in Table 5.

Normally, heavy metals accumulating in soil are present in stable form, adsorbing on clay minerals, or forming organo-mineral compounds with organic mineral in the soil or near-surface depths (Tok, 1997). Cd (cadmium), which is toxic to plants, animals and humans even at a very low concentration, is one of the most important heavy metals to be noted. $\mathrm{Cd}$ accumulation causes the inhibition of photosynthesis, lowering the transpiration rate through the stomatal closure, restriction of chlorophyll synthesis and degradation of total chlorophyll in plants (Bergmann, 1992; Zincircioğlu, 2013). During the present study, Cd was determined in a range of 1.9 to $2.1 \mathrm{ppm}$. However, a minimum concentration of $\mathrm{Cd}$ content was found in plants collected from L5 (İşhanı) and there was little difference in the $\mathrm{Cd}$ content of the different plant parts. Cutler and Rains (1974) reported that the amount of cadmium decreased from the root to the top, while Soon (1998) found $\mathrm{Cd}$ in the range of $20-100 \mu \mathrm{g} / \mathrm{kg}$ in plant tissues. 
$\mathrm{Pb}$ (lead) is one of the heavy metals that cause environmental pollution and which is quite harmful to human health. Tetra ethyl lead is the main source of $\mathrm{Pb}$ which is produced from the gasoline used in motor vehicles. Normally lead accumulates in the blood or soft tissues, resulting in toxicity in the human body. Lead toxicity or poisoning in humans may result in brain damage or even death. Infants and children are very sensitive to pollution and chronic poisoning of $\mathrm{Cd}$ may lead to mental retardation, learning disorders and hyperactivity, blood pressure elevation and chronic anemia (Vural, 1993; Çağlarırmak ve Hepçimen, 2010). Yoon et al. (2006) found $2-1183 \mathrm{mg} / \mathrm{kg} \mathrm{Cd}$ concentrations in the plants growing in an area of maximum heavy metal pollution. Başar and Aydinalp (2005) reported that the concentrations of lead determined in the peach leaf and fruit differed.

In the hereby study, the lowest lead content was determined in the plant roots (93.7 ppm) collected from L4 (Şarkışla 2. location), while the maximum concentration of lead was obtained from the roots of plants collected from L7 (CU Campus-N) (525 ppm). There was also a difference between the leaves and roots of the plants in respect of lead concentrations.

Metals such as $\mathrm{Cu}$ (copper) and $\mathrm{Zn}$ (zinc), which are essential for both plants and humans, are naturally present in nature, although higher concentrations result in harmful effects. In plants, $\mathrm{Zn}$ regulates metabolic events and plays a role in enzyme activity (Allan, 1997; Okcu et al., 2009).

Kaçar and Katkat (2006) showed that zinc levels in tealeaves varied between $24-60 \mathrm{mg} / \mathrm{kg}$ during three different periods of shoot growth. Different plants have different abilities of obtaining $\mathrm{Zn}$ from the soil. According to different researchers, the plant root structure is the main factor in $\mathrm{Zn}$ availability in plants. Zinc accumulates in different proportions in various parts of the plant, and in the current study, the amount of zinc in the roots and leaves was different, with the highest zinc value determined at the L1 (Leblebici) gateway (80.6 ppm).
Co varied among the different organs of the plants and was determined in the range of 2.3-8. The lowest amount of Co was also determined within the plants in the campus area $(2.3 \mathrm{ppm})$ where the vehicle traffic was low. The highest concentration $(8 \mathrm{ppm})$ of Co was detected in the plants collected off campus where there was heavy vehicle traffic.

When the plant samples collected from the different locations were analysed for $\mathrm{Cr}$ concentration, the lowest $\mathrm{Cr}$ level (5.6 ppm) was found in the first region of the Sarkışla district and the highest amount (25.4 ppm) was present in the region of the L1 gateway. When the Cr content of the root and leaves of the plant were compared, it was seen that there was a difference between these values. The highest content of $\mathrm{Ni}$ was detected in the samples collected off campus (36.3 ppm), while the lowest Ni content $(5.6 \mathrm{ppm})$ was found in the samples from the first region of the Şarkışla district. It has been reported that in plants, Co is generally present in a range of 0.1 to $10 \mathrm{ppm}$ (Bakkaus et al., 2005), while $\mathrm{Cr}$ exists in trace amounts varying between 3 and 100 $\mu \mathrm{g} / \mathrm{mg}$ (Welch and Cary, 1975).

Medicinal and aromatic plants have many important essential and beneficial elements. However, as plants may be contaminated with heavy metals from absorption, serious health problems may arise in people who consume these plants. Therefore, the determination of mineral nutrient and heavy metal accumulation is significant (Ozyigit et al., 2017).

According to the results of the analyses in the present survey, while the minimum concentration of $\mathrm{Cd}$ content was in plants collected from L5 (İşhani) (1.9 ppm), there was little difference in the $\mathrm{Cd}$ content of the different plant parts. The lowest $\mathrm{Pb}$ content was determined in the plant roots $(93.7 \mathrm{ppm}$ ) collected from L4, while the maximum concentration of lead was obtained from the roots of plants collected from L7 (525 ppm). It was determined that the areas where the plants were growing had an impact in terms of the elements in the plant content.

Table 5. Heavy metal ratios in the leaves and roots of Echium italicum plant (ppm)

\begin{tabular}{ccccccccc}
\hline Location No & Plant parts & $\mathrm{Cd}$ & $\mathrm{Co}$ & $\mathrm{Cr}$ & $\mathrm{Ni}$ & $\mathrm{Pb}$ & $\mathrm{Zn}$ \\
\hline L1 & Leaf & $2.1 \pm 0.03$ & $3.7 \pm 0.02$ & $19.3 \pm 0.03$ & $22.3 \pm 0.05$ & $179 \pm 1.2$ & $37.4 \pm 0.03$ & $44.8 \pm 0.3$ \\
(Leblebici) & Root & $2.1 \pm 0.03$ & $6.5 \pm 0.02$ & $25.4 \pm 0.09$ & $31.27 \pm 0.06$ & $449 \pm 0.6$ & $80.6 \pm 0,03$ & $114 \pm 0.5$ \\
L2 & Leaf & $2.1 \pm 0.02$ & $3 \pm 0.02$ & $16.9 \pm 0.03$ & $21.4 \pm 0.1$ & $145 \pm 3.5$ & $35.2 \pm 0.07$ & $70.7 \pm 2.5$ \\
(Gemerek) & Root & $2.0 \pm 0.02$ & $4.8 \pm 0.02$ & $10.9 \pm 0.02$ & $13.6 \pm 0.07$ & $95 \pm 3$ & $22.4 \pm 0.05$ & $24.4 \pm 0.5$ \\
L3 & Leaf & $2 \pm 0.02$ & $4.4 \pm 0.04$ & $11.7 \pm 0.03$ & $13.4 \pm 0.03$ & $77.3 \pm 2.5$ & $27.6 \pm 0.1$ & $44.1 \pm 0.1$ \\
(Șarkışla 1. Location) & Root & $2 \pm 0.02$ & $3.9 \pm 0.03$ & $5.6 \pm 0.006$ & $5.6 \pm 0.01$ & $112.3 \pm 2.5$ & $12.4 \pm 0.08$ & $11.3 \pm 0.06$ \\
L4 & Leaf & $1.93 \pm 0.03$ & $2.9 \pm 0.02$ & $12 \pm 0.02$ & $23.1 \pm 0.04$ & $147 \pm 1.2$ & $28.8 \pm 0.1$ \\
(Șarkışla 2. Location) & Root & $2.03 \pm 0.04$ & $3,7 \pm 0.02$ & $7.5 \pm 0.04$ & $14.3 \pm 0.02$ & $93.7 \pm 0.6$ & $11.8 \pm 0.03$ & $3.2 \pm 0.1$ \\
L5 & Leaf & $1.9 \pm 0.01$ & $4.41 \pm 0.03$ & $2.3 \pm 0.03$ & $6.6 \pm 0.05$ & $61 \pm 1$ & $17.2 \pm 0.03$ & $26.3 \pm 0.3$ \\
(İşhanı) & Root & $1.9 \pm 0.02$ & $2.3 \pm 0.02$ & $8.5 \pm 0.02$ & $14.04 \pm 0.05$ & $182 \pm 2$ & $16.4 \pm 0.03$ & $68.3 \pm 1.1$ \\
L6 & Leaf & $2.1 \pm 0.02$ & $3.9 \pm 0.02$ & $4.5 \pm 0.005$ & $10.3 \pm 0.04$ & $30, \pm 0.6$ & $22.4 \pm 0.05$ & $20.1 \pm 0.1$ \\
(CU Campus) & Root & $2 \pm 0.006$ & $6.9 \pm 0.04$ & $16.1 \pm 0.1$ & $23.9 \pm 0.03$ & $455 \pm 0.6$ & $34 \pm 0.06$ & $70.6 \pm 0.3$ \\
L7 (CU Campus-N) & Leaf & $2.05 \pm 0.03$ & $5.8 \pm 0.02$ & $8.3 \pm 0.03$ & $11.4 \pm 0.01$ & $169 \pm 1$ & $16.7 \pm 0.1$ & $26.3 \pm 0.3$ \\
& Root & $2.03 \pm 0.01$ & $8 \pm 0.02$ & $23 \pm 0.02$ & $36.3 \pm 0.2$ & $525 \pm 0.6$ & $31.5 \pm 5.9$ & $73.9 \pm 0.4$ \\
\hline
\end{tabular}


428

\section{Conclusions}

The present study was conducted within the borders of the province of Sivas, along a Southwest-Northeast line. Samples of Echium italicum L. plants were collected from 7 separate locations defined in this area and laboratory analyses were applied to determine the concentrations of the elements of $\mathrm{Cd}, \mathrm{Co}, \mathrm{Cr}, \mathrm{Ni}, \mathrm{Pb}, \mathrm{Cu}$ and $\mathrm{Zn}$. Heavy metal pollution was determined in the analyses and higher values of these elements were obtained in samples from areas where there was heavy traffic. These locations were seen to be L4, L5 and L6 which were closer to the city centre. Therefore, it can be clearly understood that medicinal and aromatic plants should be collected from natural areas with little or no motor vehicle traffic for there to be no risk of heavy metal pollution.

\section{References}

Allan R (1997). Introduction: mining and metals in the environment. Journal of Geochemical Exploration 58:95-100.

Alloway WH (1968). Agronomic controls over environmental cycling of trace elements. Advances in Agronomy 20:235-274.

Alloway BJ (1990). Heavy metals in soils. Blackie and Sou Ltd., Glasgow and London.

Anonymous (2005). Toprak Kirliliginin Kontrolu Yonetmeligi. 31 Mays 2005 Tarih ve 25831 Saylı Resmi Gazete, Ankara pp 33-44.

Bakkaus E, Gouget B, Gallien JP, Khodja H, Carrot F, Morel JL, Collins R (2005). Concentration and distribution of cobalt in higher plants: The use of micro-PIXE spectroscopy. Nuclear Instruments and Methods in Physics Research B 321:350-356.

Baloch FS, Karakoy T, Demirbas A, Toklu F, Ozkan H, Hatipoglu R (2014). Variation of some seed mineral contents in open pollinated faba bean (Vicia faba L.) landraces from Turkey. Turkish Journal of Agriculture and Forestry 38:591-602.

Basar H, Aydinalp C (2005). Heavy metal contamination in peach trees irrigated with water from a heavily polluted creek. Journal of Plant Nutrition 28(11):2049-2063.

Bergmann (1993). Ernaehrungsstoerungen bei Kulturpflanzen. Dritte Erweiterte Auflage, Gustav Fisher VerleagJena, Stutgart.

Berti M, Johnson BL, Dash S, Fischer S, Wilckens R, Hevia F (2007). Echium: a source of stearidonic acid adapted to the northern Great Plains in the US, In: Janick J, Whipkey A(Eds), Issues in New Crops and New Uses, ASHSPress, Alexandriapp 120-125.

Bourrelier PH, Bertelin J (1998). Contamination des sol par les elements en taraces: Les risques et leur gestion. Academie des Sciences, rapport no 42, Lavoisier, Paris.

Cutler JM, Rains DW (1974). Characterization of cadmium uptake by plant tissues. Plant Physiology 54:67-71.

Coupland K(2008). Stearidonic acid: A plant produced omega3 PUFA and a potential alternative for marine oil fatty acids. Lipid Technology 20(7):152-154.

CaglarırmakN, Hepcimen AZ (2010). Agr Metal Toprak Kirliliginin Gida Zincirive Insan Saglıgna Etkisi. Akademik Gıda 8(2):31-35.

Dixon JB (1989). Kaolin and serpentine group minerals. In: Dixon JB,
Weed SB (Eds). Minerals in soil environments. 2nd ed. SSSA Book Ser. No.1.SSSA, Madison WIpp 467-525.

Edmondson JR (1978). Echium. In: Davis PH (Ed). Flora of Turkey and theEast Aegean Islands. Edinburgh. The University Press 6:318-24.

El-Bassam N, Tgetjen C (1977). Municipal sludge as organic fertilizer with special reference to the heavy metals constituents. In: Soil organic matter studies. Vienna, IAEE Vol. 2.

Eruygur N (2012). Turkiye'de Yetisen Bazı Echium Turlerinin Yara Iyilestirici Aktivitesinin Arastırlması. Gazi Universitesi, Doktora Tezi.

Fujita TES, Tabata M, YesiladaE, Honda G, Takeda Y, Tanaka T, Takaishi Y (2013). Traditional medicine in Turkey VII. Folk medicine in middle and west Black Sea regions. Economic Botany 49(4):406422.

Haktanır K, Arcak S, Ergul G (1995). Yol Kenarlarındaki Topraklarda Trafikten Kaynaklanan Agr Metallerin Birikimi. Journal of Engineeringand Environmental Sciences 19(6):423-432.

Horvath A (1995). Soil lead content in Hungary. Nepegeszsegugy 76(4):143-157.

Kabata-Pendias A, Pendias H (1992). Trace elements in soils and plants. $2^{\text {nd }}$ Edition CRCPress, Boca Raton, Ann Arnbor London.

Kaçar B, Katkat V (2006). Bitki Besleme. Nobel Yayın No:849. Fen Bilimleri30(5).

Kacar B, Inal A (2008). Bitki Analizleri. Nobel Yayınları No: 1241, Ankara.

Karakoy T, Erdem H, Baloch FS, Toklu F, Eker S, Kilian B, Ozkan H (2012). Diversity of macro- and micronutrients in the seeds of lentil landraces. The Scientific WorldJournal 1-9.

Karakoy T, Baloch, FS, Toklu F, Ozkan H (2014). Variation for selected morphological and quality-related traits among 178 faba bean landraces collected from Turkey. Plant Genetic Resources: Characterization and Utilization 12:5-13.

Kloke A (1980). Orientierungsdaten fuer Tolerierbare Gesamtgehalte einiger Elemente in Kulturboden Mitt. VDLUFA 1-3:9-11.

Linzon SN (1978). Phytotoxicology excessive levels for contaminants in soil and vegetation. Report of Ministry of the Environment, Ontorio, Canada.

Mengel K (1991). Ernaehrung und Stoffwechsel der Pflanze. Gustar Fiscer VerlagJena.

Moen JET, Cornet JP, Evers CWA (1986). Soil protection and remedial actions: Criteria for decision making and standardization of requirements. 441-448. In: Contaminated soil 441-448, Springer, Dordrecht.

Mohsen A (2004). Antibacterial effect of borage (Echium amoenum) on Staphylococcus aureus. Department of Immunology, Pasteur Institute of Iran, Tehran 13164, Iran.

Morteza-Semnani K, Saeedi M, Akbarzadeh M (2009). Chemical composition and antimicrobial activity of essential oil of Echium italicum L. Journal ofEssential Oil-BearingPlants 12(5):557-561.

Okcu M, Tozlu E, Kumlay AM, Pehluvan M (2009). Agr metallerin bitkiler üzerine etkileri. Alınteri 17:1426.

Ozyigit II, Yalcin B, Turan S, Saracoglu IA, Karadeniz S, Yalcin IE, Demir $\mathrm{G}$ (2017). Investigation of heavy metal level and mineral nutrient status in widely used medicinal plants' leaves in Turkey: Insights into health implications. Biological Trace Element Research 182(2):387-406.

Pardo F, Perich F, Torres R, Delle Monache F (2000). Stigmast-4-ene-3,6- 
dione an unusual phytotoxic sterone from the roots of Echium vulgare $\mathrm{L}$. Biochemical Systematics and Ecology 28(9):911-913.

Rechinger KH (1967). Flora Iranica. Akademische Druck-U.Verlagsanstalt, Graz-Austria 48,pp 214.

Robinson BH (1997). The phytoextraction of heavy metals from metalliferous soils. PhD Dissertation. Massey University, New Zealand.

Rodríguez-Bocanegra J, Roca1 N, Febrero A, Bort J (2018). Assessment of heavy metal tolerance in two plant species growing in experimental disturbed polluted urban soil. Journal of Soils and Sediments 18(6):2305-2317.

Schwertmann V, Huit M (1975). Erosionsbedingte Stoffverteilung in zwei hopfengenutzten Kleinlandschaften der Hallertau (Bayern). Zeitschrift für Pflanzenernährungund Bodenkunde 138(45):397-405.

Smith KA (1990). Manganese and cobalt in heavy metals in soils. John Wiley and Sons Inc, New York.

Soon YK (1998). Determination of cadmium, chromium, cobalt, lead and nickel in plant tissue. In: Kalra YP (Ed). Handbook of references methods for plant analysis, CRC Press, New York pp 193-198.

Tabata M, Sezik E, Honda G, Yesilada E, Fukui H, Goto K, Ikeshiro Y (1994). Traditional medicine in Turkey III. Folk medicine in East Anatolia, Van and Bitlis Provinces. Pharmaceutical Biology 32(1):3-12.

Tong MM, Gao WJ, Jiao WT, Zhou J, Li YY, He LL, Hou RY (2017). Uptake, translocation, metabolism, and distribution of gyphosate in non-target tea plant (Camellia sinensis L.). Journal of Agricultural and Food Chemistry 65:7638-7646.
Tok HH (1997). Cevre Kirliligi. Anadolu Matbaa Ambalaj San. Tic. Ltd. Sti, Istanbul pp 266-283

Yıldırım A, Ekin T (2003). Orta Anadolu Bolgesi Yabancı Ot Florası. Bitki Koruma Bulteni43:1-98.

Vural H (1993). Agr metal iyonlarının gdalarda olusturdugu kirlilikler. Cevre Dergisi 8:3-8.

Yoon J, Cao X, Zhou Q, Ma LQ (2006). Accumulation of Pb, Cu and Zn in native plants growing on a contamined Florida site. Science of the Total Environment 368:456-464.

Zincircioglu N (2013). Investigation of the heavy metal contents of some agricultural lands in the region of Manisa-Akhisar. Ege Universitesi Ziraat Fakultesi Dergisi 50(3):333-339.

Welch RM, Cary EE (1975). Concentration of chromium, nickel and vanadium in plant materials. Journal of Agricultural and Food Chemistry 23:479-482.

White PJ (2012). Plant stress physiology. School of Agricultural Science. University of Tasmania, Private Bag 54, Hobart, Australia, ISBN: 9781845939953, Chapter 10 (Heavy metal toxicity in plants), DOI: 10.1079/9781845939953.0000.

Wu DM, Yu XI, Chu SS, Jacobs DF, Wei XH, Wang C, Long FL, Chen $\mathrm{XY}$,ZengSC (2018). Alleviation of heavy metal phytotoxicity in sewage sludge by vermicomposting with additive urban plant litter. Science of the Total Environment 633:71-80. 